Article

\title{
Cytotoxic Polyketides Isolated from the Deep-Sea-Derived Fungus Penicillium chrysogenum MCCC 3A00292
}

\author{
Siwen Niu ${ }^{1,+} \oplus$, Manli Xia ${ }^{1, \dagger}$, Mingliang Chen ${ }^{1, *} \mathbb{C}$, Xiupian Liu ${ }^{1}$, Zengpeng Li $^{1}$, \\ Yunchang Xie ${ }^{2}$, Zongze Shao ${ }^{1}$ and Gaiyun Zhang ${ }^{1, *}$ \\ 1 Key Laboratory of Marine Genetic Resources, State Key Laboratory Breeding Base of Marine Genetic \\ Resources, Fujian Key Laboratory of Marine Genetic Resources, Third Institute of Oceanography, \\ Ministry of Natural Resources, 184 Daxue Road, Xiamen 361005, China; niusi123@126.com (S.N.); \\ xiam10806@163.com (M.X.); liuxiupian@tio.org.cn (X.L.); lizengpeng@tio.org.cn (Z.L.); \\ shaozongze@tio.org.cn (Z.S.) \\ 2 College of life science, Jiangxi Normal University, Nanchang 330022, China; xieyunchang@jxnu.edu.cn \\ * Correspondence: mlchen_gg@tio.org.cn (M.C.); zhgyun@tio.org.cn (G.Z.); \\ Tel.: +86-592-2195393 (M.C.); +86-592-2195833 (G.Z.) \\ + The authors contributed equally to this work.
}

Received: 13 November 2019; Accepted: 2 December 2019; Published: 5 December 2019

check for updates

\begin{abstract}
The chemical examination of the solid cultures of the deep-sea-derived fungus Penicillium chrysogenum MCCC 3A00292 resulted in the isolation of three new versiol-type analogues, namely peniciversiols A-C (1-3), and two novel lactone derivatives, namely penicilactones A and B (6 and 7), along with 11 known polyketides. The planar structures of the new compounds were determined by the comprehensive analyses of the high-resolution electrospray ionization mass spectroscopy (HRESIMS) and nuclear magnetic resonance (NMR) data, while their absolute configurations were resolved on the basis of comparisons of the experimental electronic circular dichroism (ECD) spectra with the calculated ECD data. Compound $\mathbf{1}$ is the second example of versiols featuring a 2,3-dihydropyran-4-one ring. Additionally, compounds 6 and 7 are the first representatives of $\gamma$-lactone derivatives constructed by a 1,3-dihydroxy-5-methylbenzene unit esterifying with the $\alpha$-methyl- $\gamma$-hydroxy- $\gamma$-acetic acid $\alpha, \beta$-unsaturated- $\gamma$-lactone moiety and $\alpha$-hydroxy- $\gamma$-methyl- $\gamma$-acetic acid $\alpha, \beta$-unsaturated- $\gamma$-lactone unit, respectively. All of the isolated compounds were evaluated for their cytotoxic activities against five human cancer cell lines of BIU-87, ECA109, BEL-7402, PANC-1, and Hela-S3. Compound 1 exhibited a selective inhibitory effect against the BIU-87 cell line ( $\mathrm{IC}_{50}$ $=10.21 \mu \mathrm{M})$, while compounds $\mathbf{4 , 5 , 8}$, and 12-16 showed inhibitory activities against the ECA109, $\mathrm{BIU}-87$, and $\mathrm{BEL}-7402$ cell lines with the $\mathrm{IC}_{50}$ values ranging from 7.70 to $>20 \mu \mathrm{M}$.
\end{abstract}

Keywords: Deep-sea-derived fungus; Penicillium chrysogenum; polyketides; versiol; cytotoxic activities

\section{Introduction}

Filamentous fungi are well known for their ability to produce structurally diverse secondary metabolites that feature interesting biological and pharmacological activities [1]. Recently, marine-derived-fungi, particularly deep-sea-derived fungi, have been recognized as a new source for a wide array of structurally fascinating secondary metabolites, and some of them have pharmaceutical activities [2-4]. For example, variecolortins A-C, three pairs of spirocyclic diketopiperazine enantiomers that were obtained from marine-derived fungus Eurotium sp. SCSIO F452, showed antioxidative and cytotoxic activities [5]. Simpterpenoid A, which is an unprecedented meroterpenoid that was obtained from mangrove-derived Penicillium simplicissimum MA-332, showed potent inhibitory 
activity against influenza neuraminidase in nanomolar quantities $\left(\mathrm{IC}_{50}=8.1 \mathrm{nM}\right)$ [6]. Taichunamide $\mathrm{H}$, a new indole alkaloid, was isolated from mangrove-derived fungus Aspergillus versicolor HDN11-84 [7].

Naturally occurring versiol derivatives are a rare class of fungal polyketides with an alkylated decalin nucleus. Structurally, versiol derivatives are classified into two types, according to the presence of a tetrahydropyran ring or not. As versiol was originally discovered from the fungus Aspergillus versicolor in 1975 [8], a total of 63 congeners have been discovered from several fungal genera [8-22]. Some of them showed interesting bioactivities, such as induced $\mathrm{CD}^{+} \mathrm{T}$ cell proliferation [11], antibacterial activities [12], the inhibition of colon cancer and melanoma cells [13], aromatase inhibitory activity [17], and induction neurite outgrowth in rat PC-12 cells [21]. As part of our continuing efforts to discover new and/or bioactivity secondary metabolites from the deep-sea-derived fungi [23-28], the fungus Penicillium chrysogenum MCCC 3A00292, isolated from South Atlantic Ocean at the depth of 2076 meters, was chosen for a systematic chemical investigation due to its rich metabolite profile in preliminary thin-layer chromatography (TLC) and high performance liquid chromatography (HPLC) screening. Chromatographic separation of the EtOAc extract of the fermented broth resulted in the isolation of 16 polyketides (1-16) (Figure 1), including three new versiol-type derivatives (peniciversiols A-C, 1-3), and two novel $\gamma$-lactones (penicilactones A and B, 6 and 7). In this study, the isolation, structure elucidation, and cytotoxic activities of these compounds are presented.<smiles>[3H]C1=C[C@](O)(CC(=O)Oc2cc(O)cc(F)c2)O[C@@H]1OC(=O)C[C@H]1C=C(O)C(=O)O1</smiles><smiles>[R]c1c(O)cc(C)cc1Oc1cc(C)cc(O)c1[R]</smiles><smiles>[R]c1c(O)cc(C(=O)O)cc1Oc1cc(C)cc(O)c1</smiles><smiles>Cc1cc(O)c(Oc2cc(C)cc(O)c2O)c(O)c1</smiles>

$$
\begin{aligned}
& 8 \mathrm{R}_{1}=\mathrm{R}_{2}=\mathrm{H} \\
& 9 \mathrm{R}_{1}=\mathrm{R}_{2}=\mathrm{OH}
\end{aligned}
$$<smiles>COc1cc(O)c(C(CO)CO)c2oc3cccc(O)c3c(=O)c12</smiles>

$10 \mathrm{R}=\mathrm{H}$

12

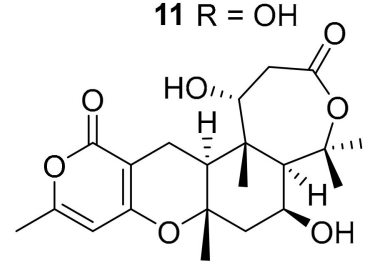

14<smiles>CN1C(=O)c2ccccc2NC(=O)C12OC2c1cccc(O)c1</smiles><smiles>CC[C@H](C)C[C@@H](C)C[C@H](CO)C[C@H](C)/C=C(C)/C=C(/C[C@H](C)C(=O)O)C(=O)O</smiles>

Figure 1. Chemical structures of 1-16 isolated from P. chrysogenum MCCC 3A00292. 


\section{Results and Discussion}

Compound 1 was obtained as yellow orange oil, and its molecular formula was established to be $\mathrm{C}_{16} \mathrm{H}_{20} \mathrm{O}_{4}$ on the basis of the positive HRESIMS spectrum $\left(\mathrm{m} / \mathrm{z} 299.1263,[\mathrm{M}+\mathrm{Na}]^{+}\right)$(Figure $\mathrm{S1}-1$ ), requiring seven degrees of unsaturation. The ${ }^{1} \mathrm{H}$ NMR spectrum exhibited two singlet methyls $\left(\delta_{\mathrm{H}} 1.17\right.$ and 1.43), one hydroxymethyl $\left(\delta_{\mathrm{H}} 3.47,3.55\right)$, five olefinic protons $\left(\delta_{\mathrm{H}} 5.38,5.54,5.92,6.34\right.$, and 7.31$)$, and one oxygenated methine $\left(\delta_{\mathrm{H}} 3.93\right)$ (Table 1$)$. The ${ }^{13} \mathrm{C}$ NMR spectrum exhibited 16 carbon resonance signals that were classified with the help of the heteronuclear single quantum coherence (HSQC) spectrum, into six olefinic carbons $\left(\delta_{C} 104.8,126.2,132.5,133.4,135.4\right.$, and 162.6) for three double bonds, a ketone carbonyl $\left(\delta_{\mathrm{C}} 200.2\right)$, two methyls $\left(\delta_{\mathrm{C}} 13.4\right.$ and 19.5), two methylenes including one oxygenated $\left(\delta_{C} 35.1\right.$ and 66.9$)$, three methines $\left(\delta_{C} 35.6,42.5\right.$, and 67.3$)$, and two nonprotonated sp ${ }^{3}$ carbons $\left(\delta_{C} 52.0\right.$ and 86.6) (Table 1). The remaining degrees of unsaturation revealed a tricyclic ring system in $\mathbf{1}$ since four of seven degrees of unsaturation were accounted by for one carbonyl and three double bonds. Comprehensive analyses of the one-dimensional (1D) $\left({ }^{1} \mathrm{H}\right.$ and $\left.{ }^{13} \mathrm{C}\right)$ and two-dimensional (2D) [HSQC, ${ }^{1} \mathrm{H}-{ }^{1} \mathrm{H}$ homonuclear chemical shift correlation spectroscopy $\left({ }^{1} \mathrm{H}^{-1} \mathrm{H}\right.$ COSY $)$, and heteronuclear multiple bond correlation (HMBC)] NMR spectra of $\mathbf{1}$ determined its structure to be related to the recently reported 12,13-dedihydroversiol [9]. The only difference was found by the presence of an additional hydroxy at $\mathrm{C}-14\left(\delta_{\mathrm{C}} 66.9\right)$, as evidenced by the COSY cross-peaks of $\mathrm{H}_{2}-2\left(\delta_{\mathrm{H}} 1.33,1.89\right) / \mathrm{H}-3\left(\delta_{\mathrm{H}}\right.$ $2.68) / \mathrm{H}-4\left(\delta_{\mathrm{H}} 5.92\right) / \mathrm{H}-3 / \mathrm{H}_{2}-14\left(\delta_{\mathrm{H}} 3.47,3.55\right)$, in addition to the HMBC correlations from the oxygenated methylene $\mathrm{H}_{2}-14$ to $\mathrm{C}-2\left(\delta_{\mathrm{C}} 35.1\right), \mathrm{C}-3\left(\delta_{\mathrm{C}} 35.6\right)$, and $\mathrm{C}-4\left(\delta_{\mathrm{C}} 133.4\right)$ (Figure 2$)$. An additional COSY correlation between $\mathrm{H}-12\left(\delta_{\mathrm{H}} 5.38\right) / \mathrm{H}-13\left(\delta_{\mathrm{H}} 7.31\right)$, as well as the HMBC cross-peaks from $\mathrm{H}-13$ to C-8 $\left(\delta_{\mathrm{C}} 86.6\right)$ and C-11 $\left(\delta_{\mathrm{C}} 200.2\right)$, and from $\mathrm{H}_{3}-16\left(\delta_{\mathrm{H}} 1.17\right)$ to $\mathrm{C}-8 / \mathrm{C}-9\left(\delta_{\mathrm{C}} 52.0\right) / \mathrm{C}-10\left(\delta_{\mathrm{C}} 42.5\right) / \mathrm{C}-11$ discerned the presence of the $\alpha, \beta$-unsaturated ketone unit residing at C-11, C-12 $\left(\delta_{\mathrm{C}} 104.8\right)$, and C-13 $\left(\delta_{\mathrm{C}}\right.$ 162.6).
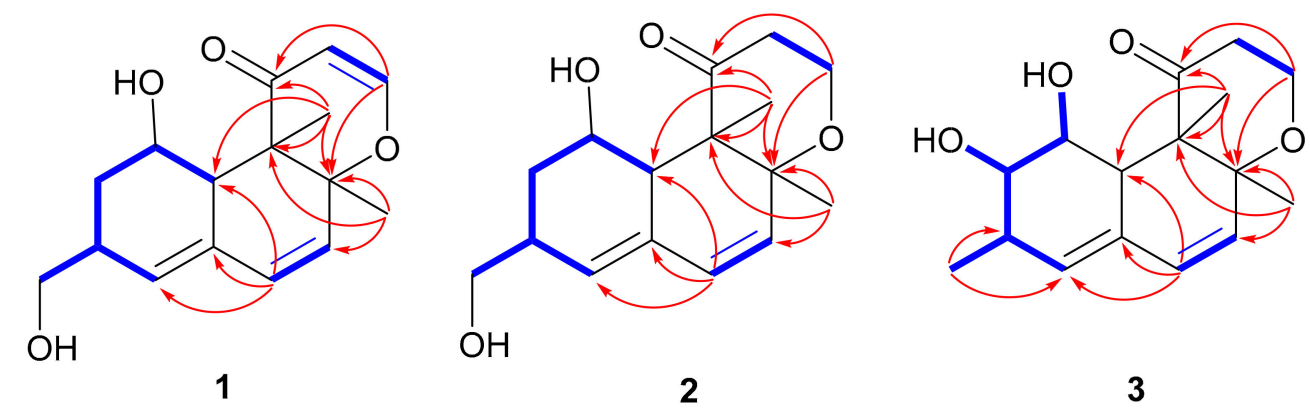

Figure 2. ${ }^{1} \mathrm{H}^{-1} \mathrm{H} \operatorname{COSY}(-)$ and key HMBC ( $)$ correlations of compounds 1-3.

The relative configuration of $\mathbf{1}$ was determined by the nuclear overhauser effect spectroscopy (NOESY) data and the coupling constants. The NOESY correlations from H-10 $\left(\delta_{\mathrm{H}} 2.79\right)$ to $\mathrm{H}-1$ $\left(\delta_{\mathrm{H}} 3.93\right) / \mathrm{H}-2 \mathrm{a}\left(\delta_{\mathrm{H}} 1.33\right)$ and from $\mathrm{H}-2 \mathrm{~b}\left(\delta_{\mathrm{H}} 1.89\right)$ to $\mathrm{H}-3$, in association with the small coupling constant $J_{\mathrm{H}-1 / \mathrm{H}-10}$ value $(3.5 \mathrm{~Hz})$ deduced the same orientation of $\mathrm{H}-1, \mathrm{H}-10$, and $\mathrm{H}_{2}-14$. Additional NOESY cross-peak of $\mathrm{H}_{3}-15\left(\delta_{\mathrm{H}} 1.43\right)$ and $\mathrm{H}_{3}-16$ and the absence of the NOESY relationship between $\mathrm{H}_{3}-16$ and $\mathrm{H}-10$ revealed that $\mathrm{CH}_{3}-15$ and $\mathrm{CH}_{3}-16$ were in the opposite face toward $\mathrm{H}-10$ (Figure 3). Therefore, the relative configuration of 1 was assigned as $1 S^{*}, 3 S^{*}, 8 S^{*}, 9 R^{*}$, and $10 S^{*}$. The theoretical ECD calculation was performed by the time-dependent density functional theory (TDDFT) method at the B3LYP/6-311 G(d,p) level while using the B3LYP/6-311 G(d,p)-optimized conformers after a conformational random search with the OPLS3 force field in order to establish its absolute configuration. The calculated ECD spectrum of $1 S, 3 S, 8 S, 9 R, 10 S-1$ was in good agreement with the experimental ECD spectrum (Figure 4), indicating $S$ configurations for C-1, C-3, C-8, and C-10, and $R$ configuration for C-9. Thus, the structure of 1 was elucidated to be a 14-hydroxy-12,13-dedihydroversiol, which was given the trivial name peniciversiol A. 
Compound 2 exhibited the molecular formula of $\mathrm{C}_{16} \mathrm{H}_{22} \mathrm{O}_{4}$, as established by the sodium adduct ion peak at $\mathrm{m} / \mathrm{z} 301.1423$ in the HRESIMS spectrum (Figure S2-1), requiring six degrees of unsaturation. The ${ }^{1} \mathrm{H}$ NMR spectrum exhibited two singlet methyls $\left(\delta_{\mathrm{H}} 1.08\right.$ and 1.22), four methylenes (two oxygenated at $\delta_{\mathrm{H}} 3.47,3.54$, and $\left.3.91,4.06\right)$, three olefinic protons $\left(\delta_{\mathrm{H}} 5.42,5.84\right.$, and 6.21$)$, and three methines (one oxygenated at $\delta_{\mathrm{H}} 3.95$ ), while the ${ }^{13} \mathrm{C}$ NMR spectrum showed 16 carbon signals that involved two methyls $\left(\delta_{C} 13.6\right.$ and 20.9$)$, four methylenes involving two oxygenated $\left(\delta_{C} 35.6,39.9,61.6\right.$, and 67.0), four olefinic carbons $\left(\delta_{C} 129.6,131.4,133.2\right.$, and 133.4), a ketone carbonyl $\left(\delta_{C} 213.7\right)$, three methines, including one oxygenated $\left(\delta_{C} 35.5,43.1\right.$, and 67.2$)$, and two nonprotonated $\mathrm{sp}^{3}$ carbons $\left(\delta_{\mathrm{C}}\right.$ 58.6 and 80.4). The above-mentioned NMR data were closely similar to those of $\mathbf{1}$, with the exception of the presence of two additional methylenes in $\mathbf{2}$ instead of two olefinic carbons of $\mathbf{1}$, revealing that $\mathbf{2}$ was a double bond hydrogenated derivative of $\mathbf{1}$. The hydrogenated position at $\Delta^{12,13}$ was confirmed by the deshielding chemical shift of $\mathrm{C}-11\left(\Delta \delta_{\mathrm{C}}+13.5\right)$, the COSY correlation of $\mathrm{H}_{2}-12\left(\delta_{\mathrm{H}} 2.22,3.03\right) / \mathrm{H}_{2}-13$ $\left(\delta_{\mathrm{H}} 3.91,4.06\right)$, and the $\mathrm{HMBC}$ cross-peaks from $\mathrm{H}_{2}-13$ to $\mathrm{C}-8\left(\delta_{\mathrm{C}} 80.4\right)$ and $\mathrm{C}-11\left(\delta_{\mathrm{C}} 213.7\right)$ and from $\mathrm{H}_{3}-16\left(\delta_{\mathrm{H}} 1.08\right)$ to $\mathrm{C}-8 / \mathrm{C}-9\left(\delta_{\mathrm{C}} 58.6\right) / \mathrm{C}-10\left(\delta_{\mathrm{C}} 43.1\right) / \mathrm{C}-11$ (Figure 2$)$. The NOESY cross-peaks from H-10 $\left(\delta_{\mathrm{H}} 3.44\right)$ to $\mathrm{H}-1\left(\delta_{\mathrm{H}} 3.95\right) / \mathrm{H}-2 \mathrm{a}\left(\delta_{\mathrm{H}} 1.44\right) / \mathrm{H}-12 \mathrm{~b}\left(\delta_{\mathrm{H}} 3.03\right), \mathrm{H}-2 \mathrm{~b}\left(\delta_{\mathrm{H}} 1.88\right)$ to $\mathrm{H}-3\left(\delta_{\mathrm{H}} 2.67\right)$, and from $\mathrm{H}_{3}-15\left(\delta_{\mathrm{H}} 1.22\right)$ to $\mathrm{H}_{3}-16$, in association with the absence of a NOESY correlation between $\mathrm{H}_{3}-16$ and $\mathrm{H}-10$ indicated that the relative configuration of $\mathbf{2}$ was same as that of $\mathbf{1}$ (Figure 3). The chiral centers of $\mathbf{2}$ were assigned to be identical to those of $\mathbf{1}$ by comparing the experimental and calculated ECD spectra of $\mathbf{2}$ (Figure 5). Therefore, $\mathbf{2}$ was established as a 12,13-hydrogenated derivative of $\mathbf{1}$ and named peniciversiol B.

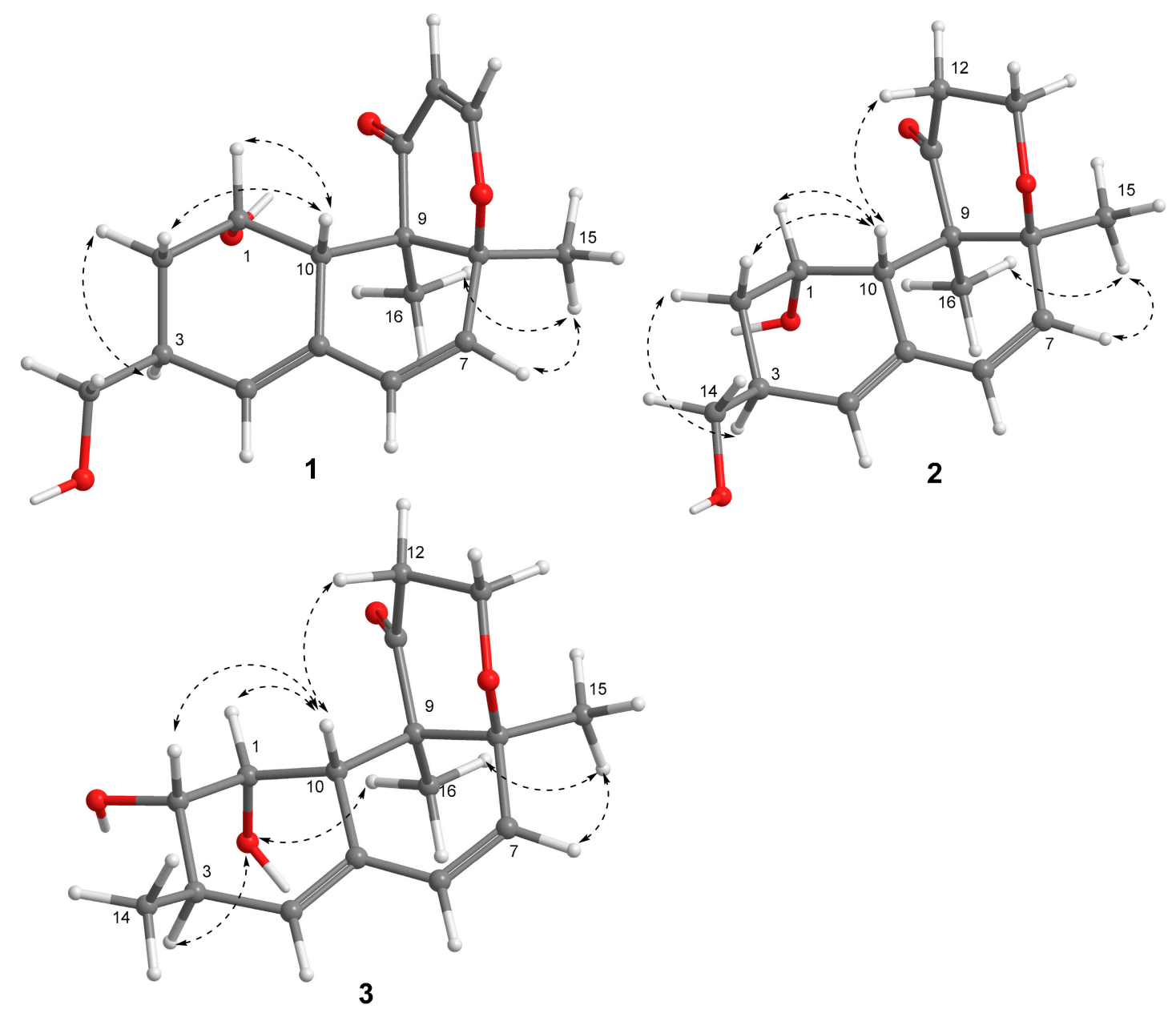

Figure 3. Selected NOESY correlations of compounds 1-3. 


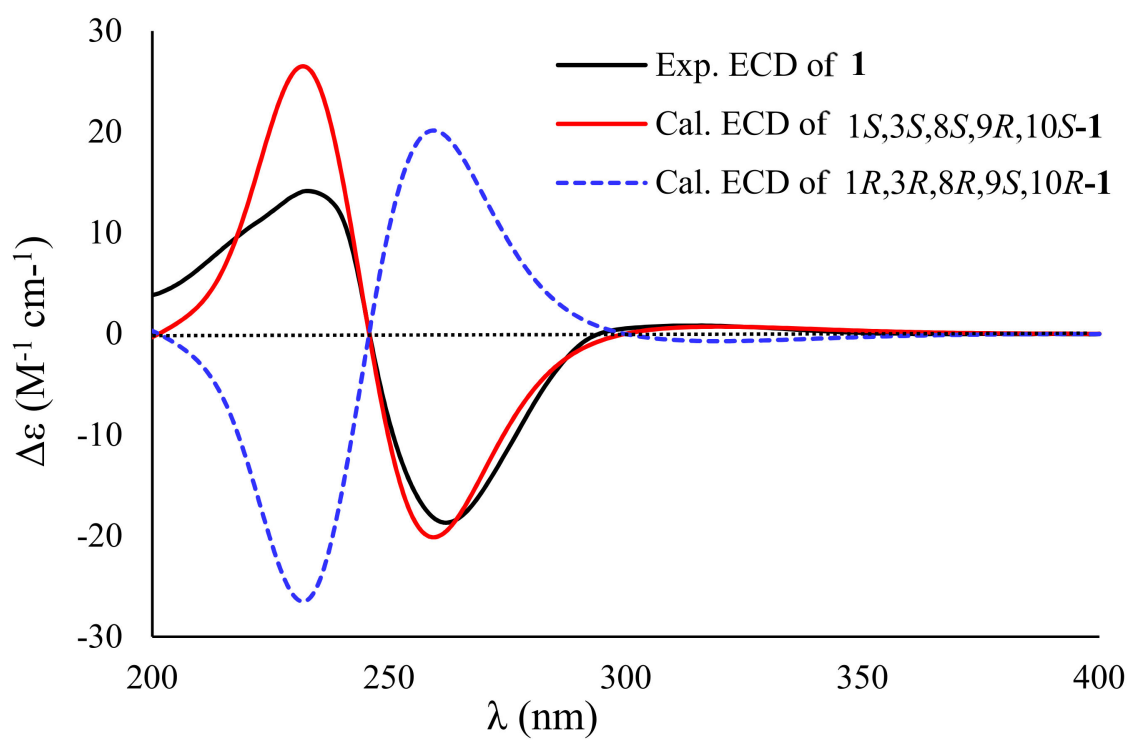

Figure 4. Experimental and calculated ECD spectra of $\mathbf{1}$ in $\mathrm{MeOH}$.

Table 1. ${ }^{1} \mathrm{H}(400 \mathrm{MHz})$ and ${ }^{13} \mathrm{C}(100 \mathrm{MHz}) \mathrm{NMR}$ data of $\mathbf{1}-\mathbf{3}$ ( $\delta$ in ppm, $J$ in Hz within parentheses).

\begin{tabular}{|c|c|c|c|c|c|c|}
\hline no. & $1^{a}$ & & $2^{a}$ & & $3^{b}$ & \\
\hline & $\delta_{\mathrm{H}}$ & $\delta_{\mathrm{C}}$ & $\delta_{\mathrm{H}}$ & $\delta_{\mathrm{C}}$ & $\delta_{\mathrm{H}}$ & $\delta_{\mathrm{C}}$ \\
\hline 1 & $3.93, \mathrm{t}(3.5)$ & $67.3, \mathrm{CH}$ & $3.95, \mathrm{t}(3.2)$ & $67.2, \mathrm{CH}$ & $3.52, \mathrm{q}(2.4)$ & $70.1, \mathrm{CH}$ \\
\hline 2 & $\begin{array}{c}1.89, \mathrm{dtd} \\
(12.5,4.8, \\
1.3) ; 1.33, \mathrm{td} \\
(12.5,1.6)\end{array}$ & 35.1, $\mathrm{CH}_{2}$ & $\begin{array}{c}1.88, \mathrm{dtd} \\
(12.6,5.0, \\
1.3) ; 1.44, \mathrm{td} \\
(12.6,1.8)\end{array}$ & 35.6, $\mathrm{CH}_{2}$ & $\begin{array}{c}3.18, \text { ddd } \\
(8.6,5.9,1.7)\end{array}$ & $75.9, \mathrm{CH}$ \\
\hline 3 & $2.68, \mathrm{~m}$ & $35.6, \mathrm{CH}$ & $2.67, \mathrm{~m}$ & $35.5, \mathrm{CH}$ & $2.36, \mathrm{~m}$ & $33.0, \mathrm{CH}$ \\
\hline 4 & 5.92, br s & $133.4, \mathrm{CH}$ & 5.84 , br s & $131.4, \mathrm{CH}$ & $5.50, \mathrm{t}(2.3)$ & $132.6, \mathrm{CH}$ \\
\hline 5 & & $132.5, \mathrm{C}$ & & $133.4, \mathrm{C}$ & & $130.2, \mathrm{C}$ \\
\hline 6 & $6.34, \mathrm{~d}(9.6)$ & $135.4, \mathrm{CH}$ & $6.21, \mathrm{~d}(9.6)$ & $133.2, \mathrm{CH}$ & $6.15, \mathrm{~d}(9.6)$ & $130.7, \mathrm{CH}$ \\
\hline 7 & $5.54, \mathrm{~d}(9.6)$ & $126.2, \mathrm{CH}$ & $5.42, \mathrm{~d}(9.6)$ & $129.6, \mathrm{CH}$ & $5.39, \mathrm{~d}(9.6)$ & $129.0, \mathrm{CH}$ \\
\hline 8 & & $86.6, \mathrm{C}$ & & $80.4, \mathrm{C}$ & & $78.1, \mathrm{C}$ \\
\hline 9 & & $52.0, \mathrm{C}$ & & $58.6, \mathrm{C}$ & & $56.5, \mathrm{C}$ \\
\hline 10 & $2.79, \mathrm{~m}$ & $42.5, \mathrm{CH}$ & $3.44, \mathrm{t}(3.2)$ & $43.1, \mathrm{CH}$ & 3.38 , overlap & $41.1, \mathrm{CH}$ \\
\hline 11 & & $200.2, C$ & & $213.7, \mathrm{C}$ & & $210.2, \mathrm{C}$ \\
\hline 12 & $5.38, \mathrm{~d}(5.9)$ & $104.8, \mathrm{CH}$ & $\begin{array}{c}3.03, \text { ddd } \\
(14.6,12.2, \\
8.8) ; 2.22, \mathrm{dd} \\
(14.6,3.0)\end{array}$ & $39.9, \mathrm{CH}_{2}$ & $\begin{array}{c}2.98, \text { ddd } \\
(14.2,12.0, \\
8.9) ; 2.11, \mathrm{dd} \\
(14.2,3.0)\end{array}$ & $38.4, \mathrm{CH}_{2}$ \\
\hline 13 & $7.31, \mathrm{~d}(5.9)$ & 162.6, $\mathrm{CH}$ & $\begin{array}{c}4.06, \mathrm{dd} \\
(11.9,8.3) \\
3.91, \mathrm{dd} \\
(11.9,3.5)\end{array}$ & 61.6, $\mathrm{CH}_{2}$ & $\begin{array}{c}3.98, \mathrm{dd} \\
(11.8,8.8) \\
3.79, \mathrm{td}(11.8, \\
3.2)\end{array}$ & $60.0, \mathrm{CH}_{2}$ \\
\hline 14 & $\begin{array}{c}3.55, \mathrm{dd} \\
(10.6,5.9) \\
3.47, \mathrm{dd} \\
(10.6,6.5)\end{array}$ & $66.9, \mathrm{CH}_{2}$ & $\begin{array}{c}3.54, \mathrm{dd} \\
(10.5,6.2) \\
3.47, \mathrm{dd} \\
(10.5,6.6)\end{array}$ & 67.0, $\mathrm{CH}_{2}$ & $1.04, \mathrm{~d}(7.2)$ & $17.8, \mathrm{CH}_{3}$ \\
\hline 15 & $1.43, \mathrm{~s}$ & $19.5, \mathrm{CH}_{3}$ & $1.22, \mathrm{~s}$ & $20.9, \mathrm{CH}_{3}$ & $1.11, \mathrm{~s}$ & $20.1, \mathrm{CH}_{3}$ \\
\hline 16 & $1.17, \mathrm{~s}$ & $13.4, \mathrm{CH}_{3}$ & $1.08, \mathrm{~s}$ & $13.6, \mathrm{CH}_{3}$ & $0.99, \mathrm{~s}$ & $13.2, \mathrm{CH}_{3}$ \\
\hline $1-\mathrm{OH}$ & & & & & $4.15, \mathrm{~d}(3.3)$ & \\
\hline 2-OH & & & & & $4.54, \mathrm{~d}(5.9)$ & \\
\hline
\end{tabular}

${ }^{\text {a }}$ Recorded in $\mathrm{CD}_{3} \mathrm{OD} .{ }^{\mathrm{b}}$ Recorded in DMSO- $d_{6}$. 
The molecular formula of 3 was determined to be $\mathrm{C}_{16} \mathrm{H}_{22} \mathrm{O}_{4}$ on the basis of the positive HRESIMS spectrum $\left(\mathrm{m} / \mathrm{z}\right.$ 301.1420, $\left.[\mathrm{M}+\mathrm{Na}]^{+}\right)$and ${ }^{13} \mathrm{C}$ NMR spectrum. The ${ }^{1} \mathrm{H}$ and ${ }^{13} \mathrm{C}$ NMR data closely resembled those of versiol [8,22], except for the presence of an extra oxymethine in 3 to replace a methylene of versiol, indicating that 3 was a hydroxylated derivative of versiol. The location of the hydroxy group at C-2 $\left(\delta_{\mathrm{C}} 75.9\right)$ was discerned by the COSY relationships of $1-\mathrm{OH}\left(\delta_{\mathrm{H}} 4.15\right) / \mathrm{H}-1\left(\delta_{\mathrm{H}}\right.$ $3.52) / \mathrm{H}-2\left(\delta_{\mathrm{H}} 3.18\right) / 2-\mathrm{OH}\left(\delta_{\mathrm{H}} 4.54\right)$, in addition to the HMBC cross-peaks from $\mathrm{H}_{3}-14\left(\delta_{\mathrm{H}} 1.04\right)$ to the oxymethine $\mathrm{C}-2, \mathrm{C}-3\left(\delta_{\mathrm{C}} 33.0\right)$, and $\mathrm{C}-4\left(\delta_{\mathrm{C}} 132.6\right)$ (Figure 2$)$. The $2 \alpha-\mathrm{OH}$ orientation was deduced by the NOESY cross-peak between $\mathrm{H}-10\left(\delta_{\mathrm{H}} 3.38\right)$ and $\mathrm{H}-2$. The relative configurations of the remaining stereogenic centers of 3 were identical to those of versiol on the basis of the NOESY correlations, as shown in Figure 3. On the basis of the nearly identical ECD spectra between $\mathbf{3}$ and $\mathbf{2}$, the absolute configuration of $\mathbf{3}$ was assigned (Figure 5). Thus, the structure of $\mathbf{3}$ was elucidated as 2-hydroxylated derivative of versiol, which was named peniciversiol C.

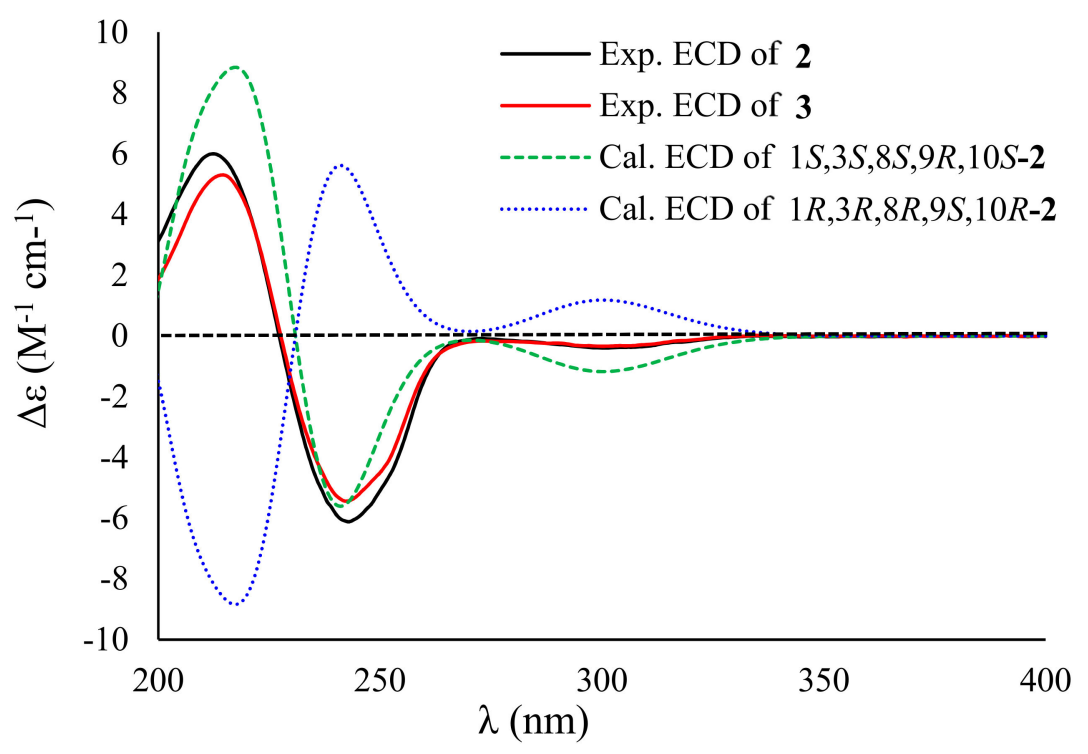

Figure 5. Experimental ECD spectra of 2 and $\mathbf{3}$ in $\mathrm{MeOH}$ and the calculated ECD spectra of $1 S, 3 S, 8 S, 9 R, 10 S-2$ and $1 R, 3 R, 8 R, 9 S, 10 R-2$.

Compound 6 exhibited a molecular formula of $\mathrm{C}_{14} \mathrm{H}_{14} \mathrm{O}_{6}$, as determined by the negative HRESIMS spectrum $\left(m / z 277.0714,[\mathrm{M}-\mathrm{H}]^{-}\right)$, requiring eight indices of hydrogen deficiency. The ${ }^{1} \mathrm{H} N M R$ spectrum (Figure S4-2) showed three aromatic protons $\left(\delta_{\mathrm{H}} 6.23,6.25\right.$, and 6.38$)$ for a 1,3,5-trisubstituted phenyl unit, two singlet methyls $\left(\delta_{\mathrm{H}} 1.71\right.$ and 2.16), one olefinic proton $\left(\delta_{\mathrm{H}} 7.33\right)$, and a methylene $\left(\delta_{\mathrm{H}}\right.$ $3.01,3.15)$ (Table 2). The ${ }^{13} \mathrm{C}$ NMR spectrum exhibited 14 carbon signals that were attributable to six aromatic carbons $\left(\delta_{C} 107.0,113.1,113.9,139.4,153.2\right.$, and 157.8) for a benzene ring, two olefinic carbons $\left(\delta_{\mathrm{C}} 132.3\right.$ and 146.0) for a double bond, two carbonyl carbons $\left(\delta_{\mathrm{C}} 169.2\right.$ and 170.5), two methyls $\left(\delta_{\mathrm{C}}\right.$ 10.0 and 21.1), a methylene $\left(\delta_{C} 41.9\right)$, and a nonprotonated $\mathrm{sp}^{3}$ carbon $\left(\delta_{C} 106.3\right)$ (Table 2$)$. Because seven of eight degrees of unsaturation were accounted for by a benzene ring, a double bond, and two carbonyl groups, the remaining degree of unsaturation revealed the presence of the other cyclic ring in 6. The COSY cross-peaks of H-2 $\left(\delta_{\mathrm{H}} 6.25\right) / \mathrm{H}-4\left(\delta_{\mathrm{H}} 6.23\right) / \mathrm{H}-6\left(\delta_{\mathrm{H}} 6.38\right)$ and the HMBC correlations from $\mathrm{H}_{3}-7\left(\delta_{\mathrm{H}} 2.16\right)$ to $\mathrm{C}-1\left(\delta_{\mathrm{C}} 139.4\right), \mathrm{C}-2\left(\delta_{\mathrm{C}} 113.9\right)$, and C-6 $\left(\delta_{\mathrm{C}} 113.1\right), \mathrm{H}-6$ to C-2/C-4 $\left(\delta_{\mathrm{C}} 107.0\right) / \mathrm{C}-5$ $\left(\delta_{\mathrm{C}} 157.8\right)$, and from $\mathrm{H}-2$ to $\mathrm{C}-3\left(\delta_{\mathrm{C}} 153.2\right) / \mathrm{C}-4 / \mathrm{C}-6$ deduced a 3-oxygenated 5-methylphenol ring (unit A). Additional HMBC cross-peaks from H-2' $\left(\delta_{\mathrm{H}} 3.01,3.15\right)$ to $\mathrm{C}-1^{\prime}\left(\delta_{\mathrm{C}} 169.2\right) / \mathrm{C}-3^{\prime}\left(\delta_{\mathrm{C}} 106.3\right), \mathrm{H}-4^{\prime}$ $\left(\delta_{\mathrm{H}} 7.33\right)$ to $\mathrm{C}-3^{\prime}$, and from $\mathrm{H}_{3}-7^{\prime}\left(\delta_{\mathrm{H}} 1.71\right)$ to $\mathrm{C}-4^{\prime}\left(\delta_{\mathrm{C}} 146.0\right), \mathrm{C}-5^{\prime}\left(\delta_{\mathrm{C}} 132.3\right)$, and $\mathrm{C}-6^{\prime}\left(\delta_{\mathrm{C}} 170.5\right)$ determined the substructural segment of unit B (Figure 6). The connection of units A and B through an ester bond between $C-3$ and $C-1^{\prime}$, as evidenced by the molecular formula of $\mathbf{6}$ and the shielding chemical shift of $C-1^{\prime}$. The simplified structures of $\mathbf{6 a}$ and $\mathbf{6 b}$ were used for the ECD calculation because only one stereogenic center $\left(C-3^{\prime}\right)$ in $\mathbf{6}$ resided in unit B. The calculated ECD data of $\mathbf{6 a}$ 
exhibited a nearly identical ECD curve to the experimental ECD spectrum of 6 , suggesting the 3'S configuration (Figure 7). Interestingly, compound 6, featuring a rare $\alpha$-methyl- $\gamma$-hydroxy- $\gamma$-acetic acid $\alpha, \beta$-unsaturated- $\gamma$-lactone moiety fusing with 1,3-dihydroxy-5-methylbenzene unit by esterification, is a novel lactone derivative that is found in nature, which was named penicilactone A.

Table 2. ${ }^{1} \mathrm{H}(400 \mathrm{MHz})$ and ${ }^{13} \mathrm{C}(100 \mathrm{MHz}) \mathrm{NMR}$ spectroscopic data of 6 and 7 in DMSO- $d_{6}$.

\begin{tabular}{|c|c|c|c|c|}
\hline \multicolumn{2}{|c|}{ Position } & \multicolumn{3}{|c|}{7} \\
\hline & $\delta_{\mathrm{H}}, \operatorname{Mult}(J$ in $\mathrm{Hz})$ & $\delta_{\mathrm{C}}$, Type & $\delta_{H}, \operatorname{Mult}(J$ in $\mathrm{Hz})$ & $\delta_{\mathrm{C}}$, Type \\
\hline 1 & & $139.4, \mathrm{C}$ & & $140.4, \mathrm{C}$ \\
\hline 2 & 6.25 , br s & $113.9, \mathrm{CH}$ & 6.45 , br s & $112.7, \mathrm{CH}$ \\
\hline 3 & & $153.2, \mathrm{C}$ & & 155.7, C \\
\hline 4 & 6.23 , br s & 107.0, $\mathrm{CH}$ & 6.38, br s & 103.0, $\mathrm{CH}$ \\
\hline 5 & & $157.8, \mathrm{C}$ & & $158.5, \mathrm{C}$ \\
\hline 6 & 6.38 , br s & $113.1, \mathrm{CH}$ & 6.45 , br s & $109.7, \mathrm{CH}$ \\
\hline 7 & $2.16, \mathrm{~s}$ & $21.1, \mathrm{CH}_{3}$ & $2.22, \mathrm{~s}$ & $21.1, \mathrm{CH}_{3}$ \\
\hline $1^{\prime}$ & & $169.2, \mathrm{C}$ & & $170.5, \mathrm{C}$ \\
\hline $2^{\prime}$ & 3.15, d (15.5); 3.01, d (15.5) & $41.9, \mathrm{CH}_{2}$ & $2.80, \mathrm{~d}(15.5) ; 2.74, \mathrm{~d}(15.5)$ & $43.1, \mathrm{CH}_{2}$ \\
\hline $3^{\prime}$ & & $106.3, \mathrm{C}$ & & $82.0, \mathrm{C}$ \\
\hline $4^{\prime}$ & 7.33 , br s & 146.0, $\mathrm{CH}$ & $6.69, \mathrm{~s}$ & $129.5, \mathrm{CH}$ \\
\hline $5^{\prime}$ & & $132.3, \mathrm{C}$ & & $142.9, \mathrm{C}$ \\
\hline $6^{\prime}$ & & $170.5, \mathrm{C}$ & & 166.3, C \\
\hline $7^{\prime}$ & $1.71, \mathrm{~s}$ & $10.0, \mathrm{CH}_{3}$ & $1.49, \mathrm{~s}$ & $25.0, \mathrm{CH}_{3}$ \\
\hline
\end{tabular}

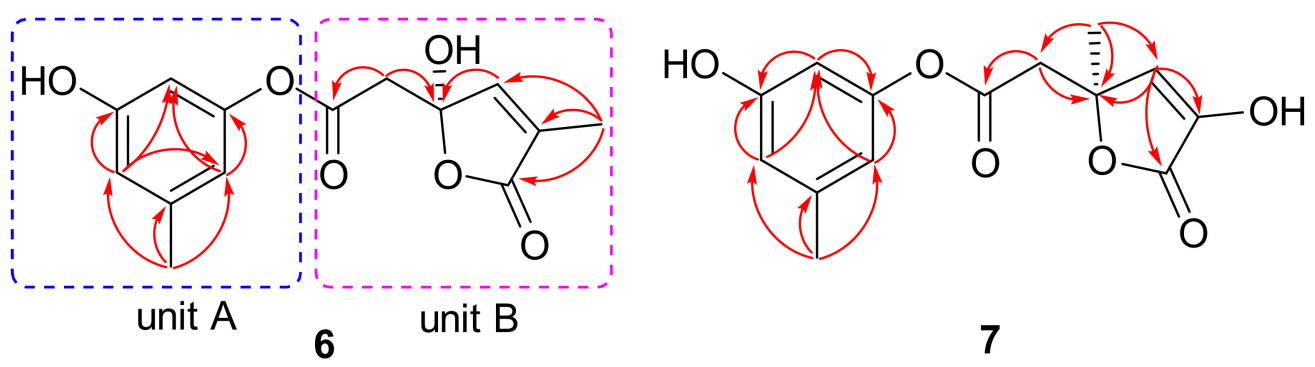

Figure 6. Selected HMBC correlations of 6 and 7.

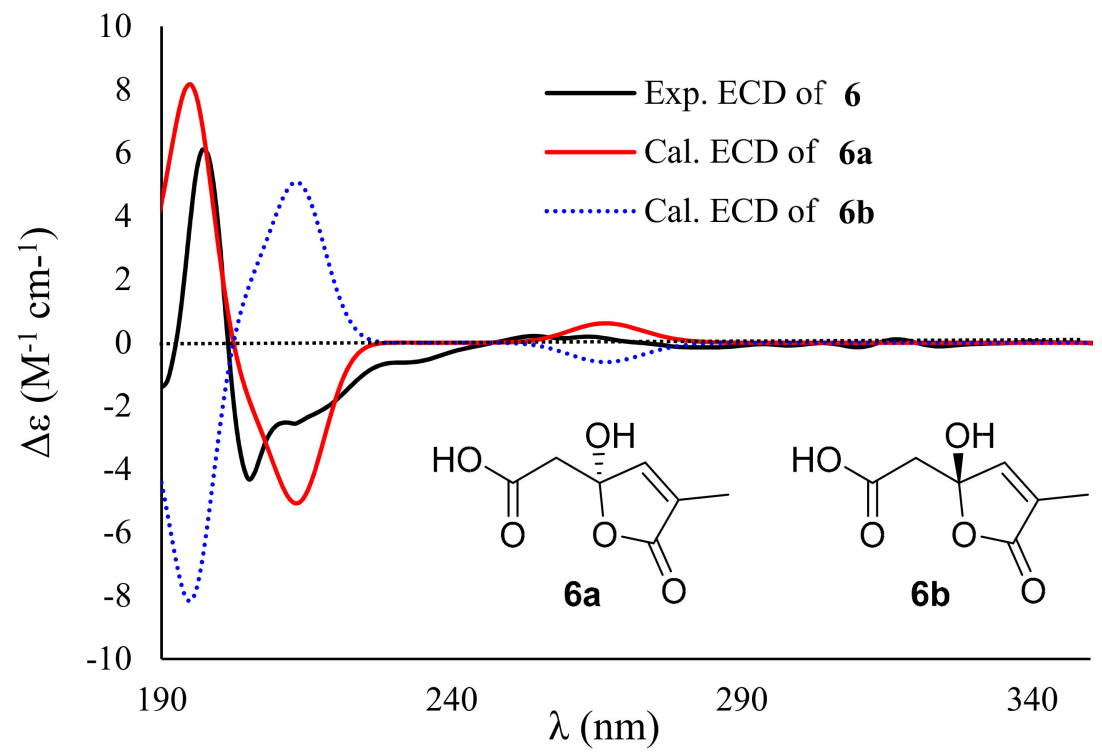

Figure 7. Experimental ECD spectra of 6 in $\mathrm{CH}_{3} \mathrm{CN}$ and the calculated ECD spectra of the corresponding simplified structures $6 \mathbf{a}$ and $\mathbf{6 b}$. 
Compound $\mathbf{7}$ had the same molecular formula as that of $\mathbf{6}$, as determined by the sodium adduct ion peak at $m / z 301.0694$ in the HRESIMS spectrum (Figure S5-1). The ${ }^{1} \mathrm{H}$ and ${ }^{13} \mathrm{C}$ NMR spectra of 7 showed the characteristic resonance signals for the 1,3,5-trisubstituted phenyl unit, which was the same to that of 6 . The obvious differences were found by the deshielding chemical shifts of $C-5^{\prime}\left(\Delta \delta_{C}\right.$ $+10.6)$ and $C-7^{\prime}\left(\Delta \delta_{C}+15.0\right)$, and the shielding chemical shifts of $C-3^{\prime}\left(\Delta \delta_{C}-24.3\right), C-4^{\prime}\left(\Delta \delta_{C}-16.5\right)$, and $C-6^{\prime}\left(\Delta \delta_{C}-4.2\right)$ compared with the corresponding ${ }^{13} C$ NMR data of 6 , revealing the position of the methyl at $\mathrm{C}-5^{\prime}$ and hydroxy at $\mathrm{C}-3^{\prime}$ in $\mathbf{6}$ were transposed in 7 . HMBCs confirmed the assumption from $\mathrm{H}_{3}-7^{\prime}\left(\delta_{\mathrm{H}} 1.49\right)$ to $\mathrm{C}-2^{\prime}\left(\delta_{\mathrm{C}} 43.1\right), \mathrm{C}-3^{\prime}\left(\delta_{\mathrm{C}} 82.0\right)$, and $\mathrm{C}-4^{\prime}\left(\delta_{\mathrm{C}} 129.5\right), \mathrm{H}-4^{\prime}\left(\delta_{\mathrm{H}} 6.69\right)$ to $\mathrm{C}-3^{\prime} / \mathrm{C}-5^{\prime}\left(\delta_{\mathrm{C}}\right.$ $142.9) / \mathrm{C}-6^{\prime}\left(\delta_{\mathrm{C}} 166.3\right)$, and from $\mathrm{H}_{2}-2^{\prime}\left(\delta_{\mathrm{H}} 2.74,2.80\right)$ to $\mathrm{C}-1^{\prime}\left(\delta_{\mathrm{C}} 170.5\right)$ and $\mathrm{C}-3^{\prime}$ (Figure 6). The other possible structure might be constructed by an ester bond between $C-5^{\prime}$ and $C-1^{\prime}$ to form a $\delta$-lactone ring because the $\mathrm{D}_{2} \mathrm{O}$ exchangeable proton $5^{\prime}-\mathrm{OH}$ was not detected in the ${ }^{1} \mathrm{H}$ NMR spectrum of 7 , as shown in Figure 8 ( $7 \mathbf{c}$ or $\mathbf{7 d}$ ). When considering the deshielding chemical shifts of $C-3^{\prime}$, the aforementioned candidate $(\mathbf{7 c}$ or $\mathbf{7 d})$ was less likely than $\mathbf{7 a}$ or $\mathbf{7 b}$. However, this assumption needed additional solid evidences. Accordingly, the ${ }^{13} \mathrm{C}$ NMR chemical shifts of the four possible structures of $7(7 \mathrm{a}-7 \mathrm{~d})$ were calculated by the GIAO method at the mPW1PW91/6-311G + (2d,p) level using the Gaussian 09 following the protocol adapted from Michael et al. [29]. The calculated ${ }^{13} \mathrm{C}$ NMR chemical shifts of $\mathbf{7 a}$ and $\mathbf{7 b}$ were in good match with the experimental data, which excluded candidates $\mathbf{7} \mathbf{c}$ and $\mathbf{7 d}$ (Figure 8). The correlation coefficient $\left(\mathrm{R}_{2}\right)$ of $7 \mathbf{a}(0.9974)$ and $7 \mathbf{b}(0.9973)$ were higher than those of $7 \mathrm{c}(0.9943)$ and $7 \mathbf{d}(0.9943)$, and the average absolute deviation of $7 \mathbf{a}(2.66 \mathrm{ppm})$ and $7 \mathbf{b}(2.68 \mathrm{ppm})$ were obviously lower than those of $7 \mathrm{c}(4.49 \mathrm{ppm})$ and $7 \mathbf{d}(4.51 \mathrm{ppm})$. Finally, the structure of $7 \mathbf{a}$ was assigned for 7 on the basis of the experimental and calculated ECD spectra (Figure 9). Noteworthily, compound 7, bearing an $\alpha$-hydroxy- $\gamma$-methyl- $\gamma$-acetic acid $\alpha, \beta$-unsaturated- $\gamma$-lactone moiety fusing with 1,3-dihydroxy-5-methylbenzene unit by esterification, is a novel lactone derivative that was discovered in nature, which was given the trivial name penicilactone $B$.

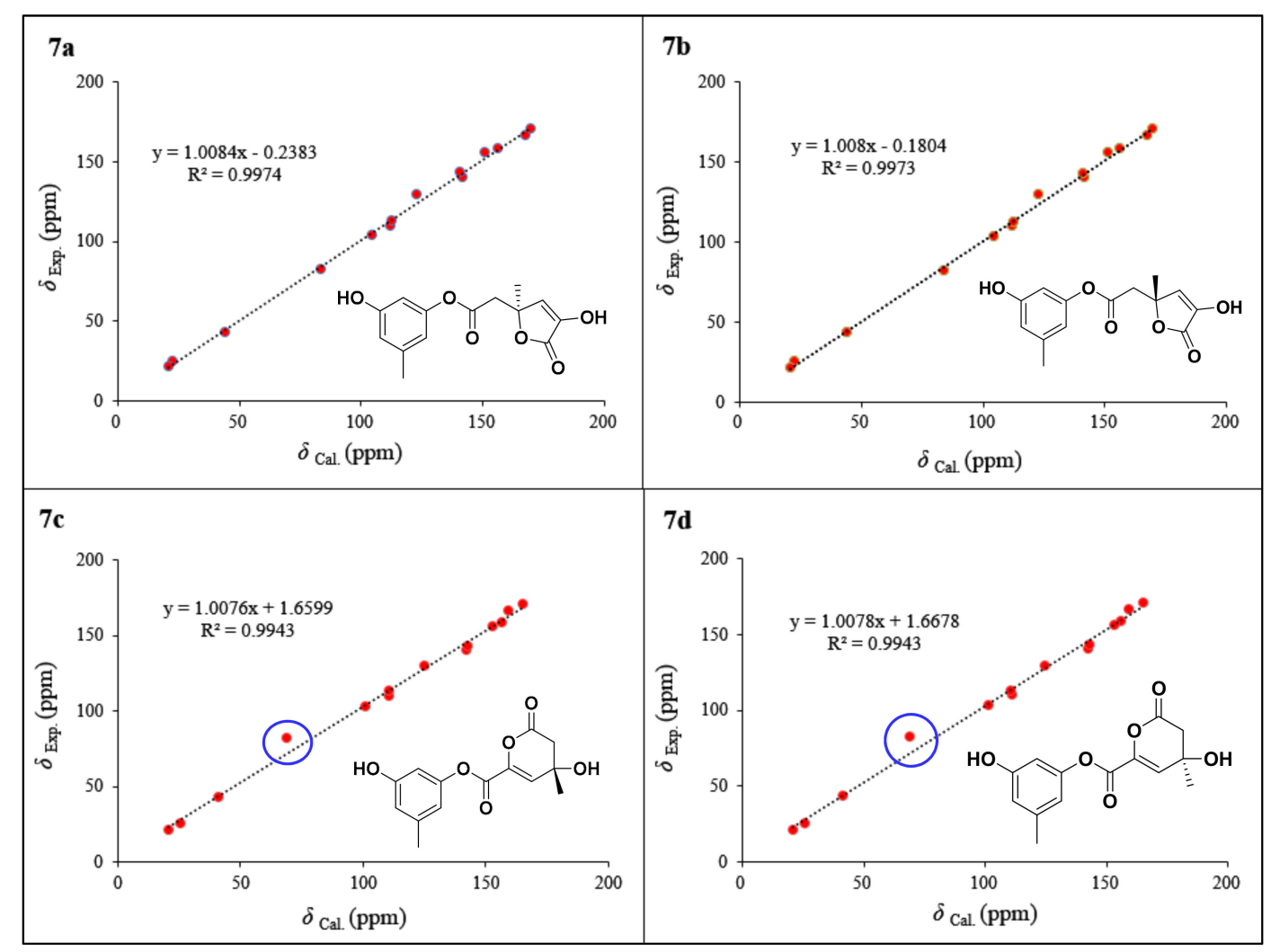

Figure 8. Correlation plots of experimental and calculated ${ }^{13} \mathrm{C} N \mathrm{NM}$ chemical shifts for the proposed structures of $\mathbf{7}(\mathbf{7 a}, \mathbf{7 b}, \mathbf{7 c}$, and $\mathbf{7 d})$ at the mPW1PW91/6-311G $+(2 \mathrm{~d}, \mathrm{p})$ level. 


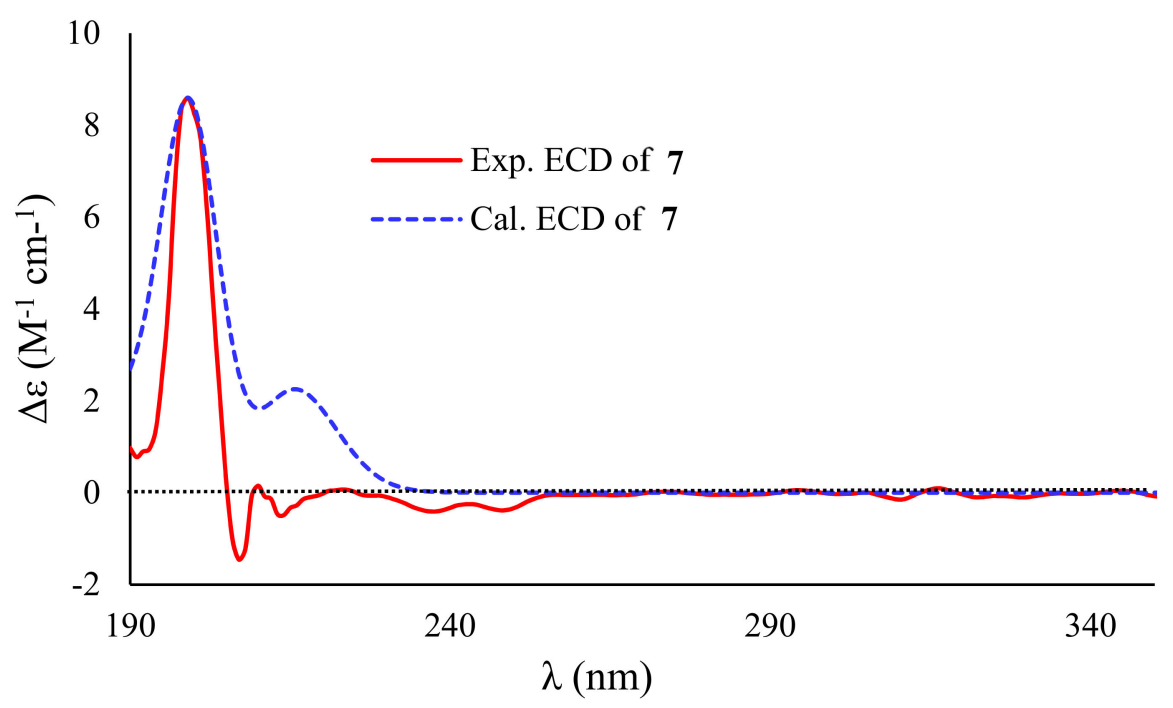

Figure 9. Experimental and calculated ECD spectra of 7 in $\mathrm{CH}_{3} \mathrm{CN}$.

Additionally, eleven known compounds were determined to be decumbenone A (4) [22], decumbenone B (5) [22], 3,3'-dihydroxy-5,5'-dimethyldiphenyl ether (8) [30,31], aspermutarubrol (9) [32], 3-hydroxy-5-(3-hydroxy-5-methylphenoxy)benzoic acid (10) [33], 3,4-dihydroxy-5-(3-hydroxy-5-methylphenoxy)benzoic acid (11) [33], violaceol-II (12) [34,35], 3,8-dihydroxy-4-(2,3-dihydroxy-1-hydroxymethylpropyl)-1-methoxyxanthone (13) [36], asperdemin (14) [37], cyclopenol (15) [38,39], and radiclonic acid (16) [40], on the basis of the comparisons of their NMR and specific rotation data with those that were reported in the literature.

As some of the versiol derivatives showed potent cytotoxic activities in the literature, all of the isolated compounds (1-16) were evaluated for their cytotoxic effects against five human cancer cell lines of BIU-87, ECA109, BEL-7402, PANC-1, and Hela-S3 by the MTT method at the initial concentration of $20 \mu \mathrm{M}$. All of the compounds displayed the inhibition rates less than $50 \%$ against two cancer cell lines of PANC-1 and Hela-S3, while compounds 1, 4, 5, 8, and 12-16, which exhibited inhibition rates more than $50 \%$, were further tested to establish their $\mathrm{IC}_{50}$ values. Compound 1 showed significantly selective inhibitory effect against BIU-87 cell line with an $\mathrm{IC}_{50}$ value of $10.21 \mu \mathrm{M}, \mathbf{1 2}$ and 16 selective inhibition ECA109 cell line with $\mathrm{IC}_{50}$ values of 8.95 and $7.70 \mu \mathrm{M}$, respectively, and 15 selective inhibition BEL-7402 $\left(\mathrm{IC}_{50}=7.81 \mu \mathrm{M}\right)$ and BIU-87 $\left(\mathrm{IC}_{50}=8.34 \mu \mathrm{M}\right)$ cell lines (Table 3). A primary analyses of the structure-activity relationships revealed that the double bond at $\Delta^{12,13}$ in $\mathbf{1}$ is necessary for the inhibition of the BIU-87 cell line, as exampled that $\mathbf{1}$ has potent inhibitory activity, while $\mathbf{2}$ displayed no activity.

Table 3. Cytotoxic activities of compounds $1,4,5,8$, and $12-16$ against five cancer cell lines.

\begin{tabular}{cccccc}
\hline & \multicolumn{5}{c}{ IC $_{\mathbf{5 0}}(\boldsymbol{\mu M})$} \\
\cline { 2 - 6 } Compounds & BIU-87 & ECA109 & BEL-7402 & PANC-1 & Hela-S3 \\
\hline $\mathbf{1}$ & 10.21 & $>20$ & $>20$ & $>20$ & $>20$ \\
$\mathbf{4}$ & $>20$ & 12.41 & $>20$ & $>20$ & $>20$ \\
$\mathbf{5}$ & $>20$ & 15.60 & $>20$ & $>20$ & $>20$ \\
$\mathbf{8}$ & 16.41 & $>20$ & $>20$ & $>20$ & $>20$ \\
$\mathbf{1 2}$ & $>20$ & 8.95 & $>20$ & $>20$ & $>20$ \\
$\mathbf{1 3}$ & $>20$ & $>20$ & 15.94 & $>20$ & $>20$ \\
$\mathbf{1 4}$ & $>20$ & $>20$ & 12.75 & $>20$ & $>20$ \\
$\mathbf{1 5}$ & 8.34 & $>20$ & 7.81 & $>20$ & $>20$ \\
$\mathbf{1 6}$ & 12.47 & 7.70 & 13.75 & $>20$ & $>20$ \\
\hline
\end{tabular}




\section{Materials and Methods}

\subsection{General Experimental Procedures}

The specific rotations were recorded on a Rudolph Autopol VI automatic polarimeter (Rudolph Reaearch Analytical) in $\mathrm{MeOH}$ at $24{ }^{\circ} \mathrm{C}$. The UV spectra were measured in $\mathrm{MeOH}$ on a UV8000 UV/Vis spectrophotometer (Shanghai Metash instrument, Shanghai, China). The ECD data were measured on a Chirascan Spectrometer (Applied Photophysics, Surrey, UK) in MeOH or MeCN. The ${ }^{1} \mathrm{H}, \mathrm{APT}, \mathrm{HSQC}, \mathrm{COSY}, \mathrm{HMBC}$, and NOESY spectra were detected by the Bruker AV-400 NMR spectrometers (Bruker, Fällanden, Switzerland). The chemical shifts are expressed in $\delta$ referenced to the solvent residual peaks of $\mathrm{CD}_{3} \mathrm{OD}\left(\delta_{\mathrm{H}} 3.31\right.$ and $\left.\delta_{\mathrm{C}} 49.0\right)$ and DMSO- $d_{6}\left(\delta_{\mathrm{H}} 2.50\right.$ and $\left.\delta_{\mathrm{C}} 39.5\right)$. The Xevo G2 Q-TOF mass spectrometer (Waters, Milford, MA, USA) was used for recording the HRESIMS spectra. Column chromatography (CC) was carried out over silica gel (200-300 mesh, Qingdao Marine Chemistry Co., Ltd., Qingdao, China), ODS (50 $\mu \mathrm{m}$, YMC Co., Ltd., Kyoto, Japan), and Sephadex LH-20 (GE Healthcare, Pittsburgh, PA, USA), respectively. Precoated silica gel plates (Qingdao Marine Chemistry Co., Ltd., Qingdao, China) were used for TLC analyses. The solvents used for isolation were all of analytical grade.

\subsection{Fungal Material}

The fungus Penicillium chrysogenum MCCC 3A00292 was isolated from the deep-sea sediment of the South Atlantic Ocean (GPS 11.4293 ${ }^{\circ}$ W, 20.8914 ${ }^{\circ}$ S) at the depth of 2076 meters during the Comra 22nd oceanic cruise in May 2011. The fungal strain was identified as P. chrysogenum on the basis of the ITS region sequence, which has $100 \%$ similarity to that of $P$. chrysogenum A096. The ITS gene sequence of this fungus was deposited in the GenBank and given the accession no. MN481191. The voucher strain is preserved at the Marine Culture Collection of China (MCCC), Third Institute of Oceanography, Ministry of Natural Resources, China, and given the deposited number MCCC 3A00292.

\subsection{Fermentation, Extraction, and Isolation}

For large-scaled fermentation, the fresh mycelia was obtained from the PDA plates at $25^{\circ} \mathrm{C}$ for three days and then inoculated to $2 \times 500 \mathrm{~mL}$ Erlenmeyer flasks each containing $200 \mathrm{~mL}$ PDB medium. Subsequently, they were cultured in rotary shaker at $180 \mathrm{rpm}$ and $28{ }^{\circ} \mathrm{C}$ for four days to obtain seed medium. Finally, the seed cultures were inoculated to $25 \times 1$ L Erlenmeyer flasks, each containing $80 \mathrm{~g}$ rice and $120 \mathrm{~mL}$ of seawater. After incubation for 30 days under static conditions at 25 ${ }^{\circ} \mathrm{C}$, the fermented solid mash was mechanically fragmented and extracted with EtOAc three times to afford an extract $(22 \mathrm{~g})$.

The extract was subjected to CC over silica gel eluting with a gradient of petroleum ether (PE) and EtOAc (1:0 $\rightarrow$ 0:1) to yield six fractions (Fr.1-Fr.6). Fraction Fr.2 $(325 \mathrm{mg})$ was further purified by $\mathrm{CC}$ over ODS eluting with $\mathrm{MeOH} / \mathrm{H}_{2} \mathrm{O}(4: 1 \rightarrow 1: 0)$ to yield eight subfractions (SFr.2-1-SFr.2-8). SFr.2-4 was further chromatographed by repeated silica gel CC eluting with $\mathrm{CH}_{2} \mathrm{Cl}_{2} / \mathrm{MeOH}(1: 0 \rightarrow 0: 1)$, $\mathrm{CH}_{2} \mathrm{Cl}_{2}$ /acetone (50:1 $\left.\rightarrow 0: 1\right)$, in association with recrystallization to obtain $2(17.5 \mathrm{mg}), \mathbf{3}(7.2 \mathrm{mg}), \mathbf{1 1}(1.9$ $\mathrm{mg}$ ), and $15(25.6 \mathrm{mg})$. Fraction Fr.3 (189 mg) was subjected to ODS CC with the mobile phase of MeOH in $\mathrm{H}_{2} \mathrm{O}(10: 1 \rightarrow 1: 0)$ to yield four subfractions (SFr.3-1-SFr.3-4). Subfraction SFr.3-2 was separated by $\mathrm{CC}$ on Sephadex LH-20 (MeOH) to afford two subfractions. The former was further purified by a semipreparative HPLC with the mobile phase of $\mathrm{CH}_{3} \mathrm{CN} / \mathrm{H}_{2} \mathrm{O}(23: 77)$ to obtain 6 (3.2 mg) and $7(1.8 \mathrm{mg})$, while the latter was further subjected to $\mathrm{CC}$ on silica gel $\left(\mathrm{CH}_{2} \mathrm{Cl}_{2} / \mathrm{MeOH}, 100: 1 \rightarrow 0: 1\right)$ to yield 12 (25.5 $\mathrm{mg})$ and 13 (14.6 mg). Fraction Fr.4 (222 mg) was subjected to CC over ODS with the mobile phase of $\mathrm{MeOH} / \mathrm{H}_{2} \mathrm{O}(5 \% \rightarrow 100 \%)$ to afford three subfractions (SFr.4-1-SFr.4-3). SFr.4-1 was further purified by $\mathrm{CC}$ over Sephadex LH-20 eluting with $\mathrm{MeOH}$ and by silica gel CC eluting with $\mathrm{CH}_{2} \mathrm{Cl}_{2} / \mathrm{MeOH}$ $(80: 1 \rightarrow 0: 1)$ to yield $4(12.2 \mathrm{mg})$ and $8(42.5 \mathrm{mg})$. SFr.4-2 was further separated by repeated CC over silica gel eluting with PE/EtOAc (1:0 $\rightarrow 0: 1)$, PE/acetone (100:1 $\rightarrow 0: 1)$, and $\mathrm{CH}_{2} \mathrm{Cl}_{2} / \mathrm{MeOH}(40: 1 \rightarrow 0: 1)$, respectively, to yield $\mathbf{9}(28.1 \mathrm{mg}), \mathbf{1 0}(12.3 \mathrm{mg})$, and $\mathbf{1 4}(4.2 \mathrm{mg})$. ODS CC using $\mathrm{MeOH}$ in $\mathrm{H}_{2} \mathrm{O}$ as the 
mobile phase $(5 \% \rightarrow 100 \%)$ chromatographed Fr.5 (172 mg) to yield six subfractions (SFr.6-1-SFr.6-6) and $16(48.2 \mathrm{mg})$. Subfraction SFr.6-4 was further separated by CC on Sephadex LH-20 (MeOH) and semipreparative HPLC eluting with $\mathrm{MeOH} / \mathrm{H}_{2} \mathrm{O}(3: 7 \rightarrow 7: 3)$ to yield $\mathbf{1}(4.0 \mathrm{mg})$ and $5(9.2 \mathrm{mg})$.

Peniciversiol A (1): yellow orange oil; $[\alpha]_{\mathrm{D}}^{24}-223\left(\right.$ c 0.12, MeOH); UV (MeOH) $\lambda_{\max }(\log \varepsilon) 239$ (4.02) nm; $\mathrm{ECD}(\mathrm{MeOH}) \lambda_{\max }(\Delta \varepsilon) 234(+14.15), 263(-18.64) \mathrm{nm} ;{ }^{1} \mathrm{H}$ and ${ }^{13} \mathrm{C}$ NMR data, see Table $1 ;$ HRESIMS $\mathrm{m} / \mathrm{z}$ $299.1263[\mathrm{M}+\mathrm{Na}]^{+}\left(\right.$calcd for $\left.\mathrm{C}_{16} \mathrm{H}_{20} \mathrm{O}_{4} \mathrm{Na}, 299.1259\right), \mathrm{m} / \mathrm{z} 575.2617[2 \mathrm{M}+\mathrm{Na}]^{+}$(calcd for $\mathrm{C}_{32} \mathrm{H}_{40} \mathrm{O}_{8} \mathrm{Na}$, 575.2621).

Peniciversiol B (2): yellow orange oil; $[\alpha]_{\mathrm{D}}^{24}-58\left(\right.$ c 0.54, MeOH); UV (MeOH) $\lambda_{\max }(\log \varepsilon) 241$ (3.98) nm; $\mathrm{ECD}(\mathrm{MeOH}) \lambda_{\max }(\Delta \varepsilon) 213(+5.98), 243(-6.12) \mathrm{nm} ;{ }^{1} \mathrm{H}$ and ${ }^{13} \mathrm{C}$ NMR data, see Table $1 ;$ HRESIMS $\mathrm{m} / \mathrm{z}$ $301.1423[\mathrm{M}+\mathrm{Na}]^{+}$(calcd for $\mathrm{C}_{16} \mathrm{H}_{22} \mathrm{O}_{4} \mathrm{Na}, 301.1416$ ).

Peniciversiol C (3): yellow orange oil; $[\alpha]_{\mathrm{D}}^{24}-89(c 0.25, \mathrm{MeOH}) ; \mathrm{UV}(\mathrm{MeOH}) \lambda_{\max }(\log \varepsilon) 241$ (3.98) nm; $\mathrm{ECD}(\mathrm{MeOH}) \lambda_{\max }(\Delta \varepsilon) 215(+5.29), 243(-5.43) \mathrm{nm} ;{ }^{1} \mathrm{H}$ and ${ }^{13} \mathrm{C}$ NMR data, see Table 1 ; HRESIMS $\mathrm{m} / z$ $301.1420[\mathrm{M}+\mathrm{Na}]^{+}$(calcd for $\left.\mathrm{C}_{16} \mathrm{H}_{22} \mathrm{O}_{4} \mathrm{Na}, 301.1416\right), \mathrm{m} / z 579.2927[2 \mathrm{M}+\mathrm{Na}]^{+}$(calcd for $\mathrm{C}_{32} \mathrm{H}_{44} \mathrm{O}_{8} \mathrm{Na}$, 579.2934).

Penicilactone A (6): colorless oil; $[\alpha]_{\mathrm{D}}^{24}-3(c 0.31, \mathrm{MeOH}) ; \mathrm{UV}(\mathrm{MeOH}) \lambda_{\max }(\log \varepsilon) 213$ (3.77), 274 (3.19) nm; ECD $\left(\mathrm{CH}_{3} \mathrm{CN}\right) \lambda_{\max }(\Delta \varepsilon) 197(+6.09), 205(-4.31) \mathrm{nm} ;{ }^{1} \mathrm{H}$ and ${ }^{13} \mathrm{C}$ NMR data, see Table 2; HRESIMS $m / z 277.0714[\mathrm{M}-\mathrm{H}]^{-}$(calcd for $\mathrm{C}_{14} \mathrm{H}_{13} \mathrm{O}_{6}, 277.0712$ ).

Penicilactone B (7): colorless oil; $[\alpha]_{\mathrm{D}}^{24}-1$ (c 0.07, MeOH); UV (MeOH) $\lambda_{\max }(\log \varepsilon) 218$ (3.71), 273 (3.13) $\mathrm{nm} ; \mathrm{ECD}\left(\mathrm{CH}_{3} \mathrm{CN}\right) \lambda_{\max }(\Delta \varepsilon) 199(+8.59), 207(-1.46) \mathrm{nm} ;{ }^{1} \mathrm{H}$ and ${ }^{13} \mathrm{C}$ NMR data, see Table 2; HRESIMS $m / z 301.0694[\mathrm{M}+\mathrm{Na}]^{+}$(calcd for $\left.\mathrm{C}_{14} \mathrm{H}_{14} \mathrm{O}_{6} \mathrm{Na}, 301.0688\right)$.

\subsection{Cytotoxicity Assay}

All of the isolated compounds were evaluated for their cytotoxic activities against five cancer cell lines (BIU-87, ECA109, BEL-7402, PANC-1, and Hela-S3) while using the MTT method. In brief, the BIU-87, ECA109, and BEL-7402 cells were cultured in RPMI 1640 medium, and the PANC-1 and Hela-S3 cells were cultured in DMEM medium, which was supplemented with $10 \%$ FBS (fetal bovine serum) in a humidified incubator $\left(5 \% \mathrm{CO}_{2}\right.$ at $\left.37^{\circ} \mathrm{C}\right)$. The cells were seeded in 96 -well plates at a density of 5000 cells/well. After $24 \mathrm{~h}$ incubation, the tested compounds were added, and incubation continued for another $48 \mathrm{~h}$. Subsequently, $10 \mu \mathrm{L}$ of 3-(4,5-dimethylthiazol-2-yl)-2,5-diphenyltetrazolium bromide (MTT) $(5 \mathrm{mg} / \mathrm{mL})$ was added into the medium and then incubated for another $1 \mathrm{~h}$. Afterwards, the medium was removed and $150 \mu \mathrm{L}$ of DMSO was added. The OD absorbance values of each well were recorded at $490 \mathrm{~nm}$ while using a SpectraMax M5 microplate reader (Molecular Devices). The isolated compounds were tested at five concentrations $(0,2.5,5,10$, and $20 \mu \mathrm{M})$ with a final DMSO concentration of $0.5 \%(\mathrm{v} / \mathrm{v})$ in each well. Dose-response curves were plotted to determine the $\mathrm{IC}_{50}$ values that were based on the averaged values of three parallel experiments while using the GraphPad Prism 7.0 software (San Diego, CA, USA).

\subsection{Computation Section}

Systematically conformational searches were performed by the Maestro 10.2 program (New York, NY, USA) at the OPLS3 molecular mechanics force field within an energy window of $3.0 \mathrm{kcal} / \mathrm{mol}$. The conformers were further optimized by the B3LYP/6-311G $(\mathrm{d}, \mathrm{p})$ level while using Gaussian 09 software (Wallingford, CT, USA) [41]. The conformers with the Boltzmann population of over $1 \%$ were chosen for the ECD calculations. The theoretical calculations of the ECD data were conducted while using the TDDFT method at the B3LYP/6-311G $(\mathrm{d}, \mathrm{p})$ level with CPCM model in MeOH for $\mathbf{1}$ and $\mathbf{2}$ and in $\mathrm{CH}_{3} \mathrm{CN}$ for 6 and 7. The ECD spectra were simulated using the SpecDis [42] by applying the Gaussian band shapes with sigma $=0.3 \mathrm{eV}$, and the finally calculated ECD data were weighted and then summed up of each stable conformers according to the Boltzmann population. The ${ }^{13} \mathrm{C} N \mathrm{NR}$ chemical shifts of compounds $\mathbf{7 a - 7 d}$ were calculated with the GIAO method at the mPW1PW91/6-311G 
$+(2 \mathrm{~d}, \mathrm{p})$ levels by the Gaussian 09 following the protocol adapted from Michael et al [29]. Finally, the calculated ${ }^{13} \mathrm{C}$ NMR chemical shift values were averaged according to the Boltzmann distribution for each conformer and then fitted to the experimental values by linear regression.

\section{Conclusions}

In the present work, three new versiol-type congeners peniciversiols $A-C$ (1-3) and two novel $\gamma$-lactone derivatives penicilactones A and B ( 6 and 7) were isolated from the solid cultures of the deep-sea-derived fungus Penicillium chrysogenum MCCC 3A00292, along with 11 known polyketides The comprehensive analyses of the HRESIMS and NMR data, in association with comparisons of the experimental and calculated ECD spectra for configurational assignments, determined the structures of new compounds. Compound 1 represents the second example of versiols featuring a 2,3-dihydropyran-4-one ring, while 6 and 7 are first representatives of the $\gamma$-lactone derivatives constructed by a 1,3-dihydroxy-5-methylbenzene unit separately esterifying with the $\alpha$-methyl- $\gamma$-hydroxy- $\gamma$-acetic acid $\alpha, \beta$-unsaturated- $\gamma$-lactone moiety and $\alpha$-hydroxy- $\gamma$-methyl- $\gamma$-acetic acid $\alpha, \beta$-unsaturated- $\gamma$-lactone unit. Compound 1 exhibited a selective inhibitory effect against the BIU-87 cell line $\left(\mathrm{IC}_{50}=10.21 \mu \mathrm{M}\right)$, while $\mathbf{1 6}$ showed potent inhibitory activities against the ECA109, BIU-87, and BEL-7402 cell lines with the $\mathrm{IC}_{50}$ values of $7.70,12.47$, and $13.75 \mu \mathrm{M}$, respectively, and compounds 4, 5, 8, and 12-15 showed different inhibitory activities against the BIU-87, ECA109, and BEL-7402 cell lines, with the $\mathrm{IC}_{50}$ values ranging from 7.81 to $>20 \mu \mathrm{M}$, indicating their potential applications for further development as antitumor lead compounds.

Supplementary Materials: The following are available online at http://www.mdpi.com/1660-3397/17/12/686/s1. HRESIMS, ${ }^{1} \mathrm{H}$, APT, HSQC, COSY, and HMBC spectra of 1-3, 6, and 7; NOESY spectra of 1-3.

Author Contributions: S.N. and M.X. isolated and determined the structures; S.N., X.L., and Z.S. isolated and identified the deep-sea-derived fungus; Z.L. and M.C. tested the cytotoxic activities; Y.X. carried out the ECD calculations; G.Z. designed and coordinated the study; S.N. wrote the paper, while critical revision of the publication was performed by all authors.

Funding: This research was funded by the Scientific Research Foundation of Third Institute of Oceanography, MNR (No. 2018018), the China Ocean Mineral Resources R \& D Association Program (DY135-B2-08), and the National Natural Science Foundation of China (41606185).

Conflicts of Interest: The authors declare no conflict of interest.

\section{References}

1. Schueffler, A.; Anke, T. Fungal natural products in research and development. Nat. Prod. Rep. 2014, 31, 1425-1448. [CrossRef] [PubMed]

2. Khalifa, A.M.S.; Elias, N.; Farag, A.M.; Chen, L.; Saeed, A.; Hegazy, F.M.E.; Moustafa, S.M.; Abd El Wahed, A.; Al Mousawi, M.S.; Musharraf, G.S.; et al. Marine natural products: A source of novel anticancer drugs. Mar. Drugs 2019, 17, 481. [CrossRef] [PubMed]

3. Carroll, A.R.; Copp, B.R.; Davis, R.A.; Keyzers, R.A.; Prinsep, M.R. Marine natural products. Nat. Prod. Rep. 2019, 36, 122-173. [CrossRef]

4. Daletos, G.; Ebrahim, W.; Ancheeva, E.; El-Neketi, M.; Song, W.; Lin, W.; Proksch, P. Natural products from deep-sea-derived fungi-A new source of novel bioactive compounds? Curr. Med. Chem. 2018, 25, 186-207. [CrossRef] [PubMed]

5. Zhong, W.; Wang, J.; Wei, X.; Chen, Y.; Fu, T.; Xiang, Y.; Huang, X.; Tian, X.; Xiao, Z.; Zhang, W.; et al. Variecolortins A-C, three pairs of spirocyclic diketopiperazine enantiomers from the marine-derived fungus Eurotium sp. SCSIO F452. Org. Lett. 2018, 20, 4593-4596. [CrossRef] [PubMed]

6. Li, H.L.; Xu, R.; Li, X.M.; Yang, S.Q.; Meng, L.H.; Wang, B.G. Simpterpenoid A, a meroterpenoid with a highly functionalized cyclohexadiene moiety featuring gem-propane-1,2-dione and methylformate groups, from the mangrove-derived Penicillium simplicissimum MA-332. Org. Lett. 2018, 20, 1465-1468. [CrossRef] [PubMed]

7. Li, F.; Zhang, Z.; Zhang, G.; Che, Q.; Zhu, T.; Gu, Q.; Li, D. Determination of taichunamide H and structural revision of taichunamide A. Org. Lett. 2018, 20, 1138-1141. [CrossRef] 
8. Fukuyama, K.; Tsukihara, T.; Katsube, Y.; Hamasaki, T.; Hatsuda, Y. Structure of versiol, a new methabolite from Aspergillus versicolor. Tetrahedron. Lett. 1976, 189-190. [CrossRef]

9. An, C.L.; Kong, F.D.; Ma, Q.Y.; Xie, Q.Y.; Yuan, J.Z.; Zhou, L.M.; Dai, H.F.; Yu, Z.F.; Zhao, Y.X. Chemical constituents of the marine-derived fungus Aspergillus sp. SCS-KFD66. Mar. Drugs 2018, 16, 468. [CrossRef]

10. Wijesekera, K.; Mahidol, C.; Ruchirawat, S.; Kittakoop, P. Metabolite diversification by cultivation of the endophytic fungus Dothideomycete sp. in halogen containing media: Cultivation of terrestrial fungus in seawater. Bioorg. Med. Chem. 2017, 25, 2868-2877. [CrossRef]

11. Sun, Y.Z.; Kurtan, T.; Mandi, A.; Tang, H.; Chou, Y.; Soong, K.; Su, L.; Sun, P.; Zhuang, C.L.; Zhang, W. Immunomodulatory polyketides from a Phoma-like fungus isolated from a soft coral. J. Nat. Prod. 2017, 80, 2930-2940. [CrossRef] [PubMed]

12. Li, G.; Kusari, S.; Golz, C.; Laatsch, H.; Strohmann, C.; Spiteller, M. Epigenetic modulation of endophytic Eupenicillium sp. LG41 by a histone deacetylase inhibitor for production of decalin-containing compounds. J. Nat. Prod. 2017, 80, 983-988. [CrossRef] [PubMed]

13. Cho, N.; Ransom, T.T.; Sigmund, J.; Tran, T.; Cichewicz, R.H.; Goetz, M.; Beutler, J.A. Growth inhibition of colon cancer and melanoma cells by versiol derivatives from a Paraconiothyrium species. J. Nat. Prod. 2017, 80, 2037-2044. [CrossRef] [PubMed]

14. Afiyatullov, S.S.; Leshchenko, E.V.; Berdyshev, D.V.; Sobolevskaya, M.P.; Antonov, A.S.; Denisenko, V.A.; Popov, R.S.; Pivkin, M.V.; Udovenko, A.A.; Pislyagin, E.A.; et al. Zosteropenillines: Polyketides from the marine-derived fungus Penicillium thomii. Mar. Drugs 2017, 15, 46. [CrossRef] [PubMed]

15. Ma, Y.; Li, J.; Huang, M.; Liu, L.; Wang, J.; Lin, Y. Six new polyketide decalin compounds from mangrove endophytic fungus Penicillium aurantiogriseum 328\#. Mar. Drugs 2015, 13, 6306-6318.

16. Fu, Y.; Wu, P.; Xue, J.; Wei, X.; Li, H. Versicorin, a new lovastatin analogue from the fungus Aspergillus versicolor SC0156. Nat. Prod. Res. 2015, 29, 1363-1368. [CrossRef]

17. Hewage, R.T.; Aree, T.; Mahidol, C.; Ruchirawat, S.; Kittakoop, P. One strain-many compounds (OSMAC) method for production of polyketides, azaphilones, and an isochromanone using the endophytic fungus Dothideomycete sp. Phytochemistry 2014, 108, 87-94. [CrossRef]

18. Zhuravleva, O.I.; Afiyatullov, S.S.; Vishchuk, O.S.; Denisenko, V.A.; Slinkina, N.N.; Smetanina, O.F. Decumbenone $\mathrm{C}$, a new cytotoxic decaline derivative from the marine fungus Aspergillus sulphureus KMM 4640. Arch. Pharmacal Res. 2012, 35, 1757-1762. [CrossRef]

19. Guo, H.; Feng, T.; Li, Z.H.; Liu, J.K. Five new polyketides from the basidiomycete Craterellus odoratus. Nat. Prod. Bioprospect. 2012, 2, 170-173. [CrossRef]

20. Hao, G.; Zhang, Q.H.; Jiang, M.M.; Tang, J.S.; Miao, C.D.; Hong, K.; Michio, N.; Wang, N.L.; Yao, X.S. Polyketides from a marine sponge-derived fungus Mycelia sterilia and proton-proton long-range coupling. Magn. Reson. Chem. 2008, 46, 1148-1152. [CrossRef]

21. Tsukamoto, S.; Miura, S.; Yamashita, Y.; Ohta, T. Aspermytin A: A new neurotrophic polyketide isolated from a marine-derived fungus of the genus Aspergillus. Bioorg. Med. Chem. Lett. 2004, 14, 417-420. [CrossRef] [PubMed]

22. Fujii, Y.; Asahara, M.; Ichinoe, M.; Nakajima, H. Fungal melanin inhibitor and related compounds from Penicillium decumbens. Phytochemistry 2002, 60, 703-708. [CrossRef]

23. Niu, S.; Xia, J.; Li, Z.; Yang, L.; Yi, Z.; Xie, C.; Peng, G.; Luo, Z.; Shao, Z.; Yang, X. Aphidicolin chemistry of the deep-sea-derived fungus Botryotinia fuckeliana MCCC 3A00494. J. Nat. Prod. 2019, 82, 2307-2331. [CrossRef] [PubMed]

24. Niu, S.; Tang, X.; Fan, Z.; Xia, J.; Xie, C.; Yang, X. Fusarisolins A-E, polyketides from the marine-derived fungus Fusarium solani H918. Mar. Drugs 2019, 17, 125. [CrossRef]

25. Niu, S.; Liu, Q.; Xia, J.; Xie, C.; Luo, Z.; Shao, Z.; Liu, G.; Yang, X. Polyketides from the deep-sea-derived fungus Graphostroma sp. MCCC 3A00421 showed potent antifood allergic activities. J. Agric. Food Chem. 2018, 66, 1369-1376. [CrossRef]

26. Niu, S.; Liu, D.; Shao, Z.; Proksch, P.; Lin, W. Eremophilane-type sesquiterpenoids in a deep-sea fungus Eutypella sp. activated by chemical epigenetic manipulation. Tetrahedron 2018, 74, 7310-7325. [CrossRef]

27. Niu, S.; Fan, Z.; Tang, X.; Liu, Q.; Shao, Z.; Liu, G.; Yang, X. Cyclopiane-type diterpenes from the deep-sea-derived fungus Penicillium commune MCCC 3A00940. Tetrahedron Lett. 2018, 59, 375-378. [CrossRef] 
28. Niu, S.; Fan, Z.; Xie, C.; Liu, Q.; Luo, Z.; Liu, G.; Yang, X. Spirograterpene A, a tetracyclic spiro-diterpene with a fused 5/5/5/5 ring system from the deep-sea-derived fungus Penicillium granulatum MCCC 3A00475. J. Nat. Prod. 2017, 80, 2174-2177. [CrossRef]

29. Lodewyk, M.W.; Siebert, M.R.; Tantillo, D.J. Computational prediction of ${ }^{1} \mathrm{H}$ and ${ }^{13} \mathrm{C}$ chemical shifts: A useful tool for natural product, mechanistic, and synthetic organic chemistry. Chem. Rev. 2012, 112, 1839-1862. [CrossRef]

30. Itabashi, T.; Nozawa, K.; Nakajima, S.; Kawai, K. A new azaphilone, falconensin H, from Emericella falconensis. Chem. Pharm. Bull. 1993, 41, 2040-2041. [CrossRef]

31. Ballantine, J.A.; Hassall, C.H.; Jones, B.D. Biosynthesis of phenols. XVII. Some phenolic metabolites of mutant strains of Aspergillus rugulosus. Phytochemistry 1968, 7, 1529-1534. [CrossRef]

32. Taniguchi, M.; Kaneda, N.; Shibata, K.; Kamikawa, T. Isolation and biological activity of aspermutarubrol, a self-growth inhibitor from Aspergillus sydowi. Agric. Biol. Chem. 1978, 42, 1629-1630.

33. He, P.; Tian, S.; Xu, Y.; Yu, H.; Ji, Y.; Zhu, H.; Li, J. Three new phenyl ether derivatives from Aspergillus carneus HQ889708. Helv. Chim. Acta 2015, 98, 819-822. [CrossRef]

34. Yamazaki, M.; Maebayashi, Y. Structure determination of violaceol-I and -II, new fungal metabolites from a strain of Emericella violacea. Chem. Pharm. Bull. 1982, 30, 514-518. [CrossRef]

35. Takenaka, Y.; Tanahashi, T.; Nagakura, N.; Hamada, N. Phenyl ethers from cultured lichen mycobionts of Graphis scripta var. serpentina and G. rikuzensis. Chem. Pharm. Bull. 2003, 51, 794-797. [CrossRef] [PubMed]

36. Maes, C.M.; Steyn, P.S. Polyketide-derived fungal metabolites from Bipolaris sorokiniana and their significance in the biosynthesis of sterigmatocystin and aflatoxin B1. J. Chem. Soc. Perkin Trans. 1 1984, 1137-1140. [CrossRef]

37. Yurchenko, A.N.; Smetanina, O.F.; Kalinovsky, A.I.; Pivkin, M.V.; Dmitrenok, P.S.; Kuznetsova, T.A. A new meroterpenoid from the marine fungus Aspergillus versicolor (Vuill.) Tirab. Russ. Chem. Bull. 2010, 59, 852-856. [CrossRef]

38. Martin, P.K.; Rapoport, H.; Smith, H.W.; Wong, J.L. Synthesis of cyclopenin and isocyclopenin. J. Org. Chem. 1969, 34, 1359-1363. [CrossRef]

39. Hodge, R.P.; Harris, C.M.; Harris, T.M. Verrucofortine, a major metabolite of Penicillium verrucosum var. cyclopium, the fungus that produces the mycotoxin verrucosidin. J. Nat. Prod. 1988, 51, 66-67.

40. Sassa, T.; Takemura, T.; Ikeda, M.; Miura, Y. Structure of radiclonic acid, a new plant growth-regulator produced by a fungus. Tetrahedron Lett. 1973, 2333-2334. [CrossRef]

41. Frisch, M.J.; Trucks, G.W.; Schlegel, H.B.; Scuseria, G.E.; Robb, M.A.; Cheeseman, J.R.; Scalmani, G.; Barone, V.; Mennucci, B.; Petersson, G.A.; et al. Gaussian 09; revision. D.01; Gaussian Inc.: Wallingford, CT, USA, 2009.

42. Bruhn, T.; Schaumlöffel, A.; Hemberger, Y.; Bringmann, G. SpecDis: Quantifying the comparison of calculated and experimental electronic circular dichroism spectra. Chirality 2013, 25, 243-249. [CrossRef] [PubMed] 